\title{
Adipose tissue insulin receptor and glucose transporter 4 expression, and blood glucose and insulin responses during glucose tolerance tests in transition Holstein cows with different body condition
}

\author{
H. Jaakson, ${ }^{+1}$ P. Karis, ${ }^{*}$ K. Ling, ${ }^{*}$ A. Ilves-Luht, ${ }^{*}$ J. Samarütel, ${ }^{*}$ M. Henno, ${ }^{*}$ I. Jõudu, ${ }^{*}$ A. Waldmann, $†$ \\ E. Reimann,†‡ P. Pärn,† R. M. Bruckmaier,§ J. J. Gross,§ T. Kaart,\# M. Kass, ${ }^{*}$ and M. Ots* \\ *Department of Animal Nutrition, Institute of Veterinary Medicine and Animal Sciences, Estonian University of Life Sciences, Kreutzwaldi Str. 46, \\ 51006 Tartu, Estonia \\ †Department of Reproductive Biology, Institute of Veterinary Medicine and Animal Sciences, Estonian University of Life Sciences, \\ Kreutzwaldi Str. 62, 51014 Tartu, Estonia \\ ‡Department of Pathophysiology, Institute of Biomedicine and Translational Medicine, University of Tartu, Ravila Str. 19, 50411 Tartu, Estonia \\ $\S$ Veterinary Physiology, Vetsuisse Faculty, University of Bern, Bremgartenstr. 109a, CH-3001 Bern, Switzerland \\ \#Department of Animal Genetics and Breeding, Institute of Veterinary Medicine and Animal Sciences, Estonian University of Life Sciences, \\ Kreutzwaldi Str. 46, 51006 Tartu, Estonia
}

\section{ABSTRACT}

Glucose uptake in tissues is mediated by insulin receptor (INSR) and glucose transporter 4 (GLUT4). The aim of this study was to examine the effect of body condition during the dry period on adipose tissue mRNA and protein expression of INSR and GLUT4, and on the dynamics of glucose and insulin following the i.v. glucose tolerance test in Holstein cows $21 \mathrm{~d}$ before (d -21 ) and after (d 21) calving. Cows were grouped as body condition score $(\mathrm{BCS}) \leq 3.0$ (thin, $\mathrm{T} ; \mathrm{n}=14$ ), $\mathrm{BCS}=3.25$ to 3.5 (optimal, $\mathrm{O} ; \mathrm{n}=14$ ), and $\mathrm{BCS} \geq 3.75$ (overconditioned, OC; $\mathrm{n}=14$ ). Blood was analyzed for glucose, insulin, fatty acids, and $\beta$-hydroxybutyrate concentrations. Adipose tissue was analyzed for INSR and GLUT4 mRNA and protein concentrations. During the glucose tolerance test $0.15 \mathrm{~g} / \mathrm{kg}$ of body weight glucose was infused; blood was collected at $-5,5,10$, 20, 30, 40, 50, and $60 \mathrm{~min}$, and analyzed for glucose and insulin. On $\mathrm{d}-21$ the area under the curve (AUC) of glucose was smallest in group $\mathrm{T}(1,512 \pm 33.9 \mathrm{mg} / \mathrm{dL}$ $\times$ min $)$ and largest in group OC $(1,783 \pm 33.9 \mathrm{mg} / \mathrm{dL}$ $\times \min )$, and different between all groups. Basal insulin on $\mathrm{d}-21$ was lowest in group $\mathrm{T}(13.9 \pm 2.32 \mu \mathrm{U} / \mathrm{mL})$, which was different from group OC $(24.9 \pm 2.32 \mu \mathrm{U} /$ $\mathrm{mL}$. On $\mathrm{d}-21$ the smallest AUC $5-60$ of insulin in group $\mathrm{T}(5,308 \pm 1,214 \mu \mathrm{U} / \mathrm{mL} \times \min )$ differed from the largest AUC in group OC $(10,867 \pm 1,215 \mu \mathrm{U} / \mathrm{mL}$ $\times$ min). Time to reach basal concentration of insulin in group OC (113 $\pm 14.1 \mathrm{~min})$ was longer compared with group $\mathrm{T}(45 \pm 14.1)$. The INSR mRNA abundance on d 21 was higher compared with $\mathrm{d}-21$ in groups $\mathrm{T}$ (d $-21: 3.3 \pm 0.44 ; \mathrm{d} 21: 5.9 \pm 0.44)$ and $\mathrm{O}(\mathrm{d}-21: 3.7$

Received March 16, 2017.

Accepted August 31, 2017.

${ }^{1}$ Corresponding author: hanno.jaakson@emu.ee $\pm 0.45 ; \mathrm{d} 21: 4.7 \pm 0.45)$. The extent of INSR protein expression on $\mathrm{d}-21$ was highest in group $\mathrm{T}(7.3 \pm$ $0.74 \mathrm{ng} / \mathrm{mL})$, differing from group $\mathrm{O}(4.6 \pm 0.73 \mathrm{ng} /$ $\mathrm{mL}$ ), which had the lowest expression. The amount of GLUT4 protein on $\mathrm{d}-21$ was lowest in group OC $(1.2$ $\pm 0.14 \mathrm{ng} / \mathrm{mL})$, different from group $\mathrm{O}(1.8 \pm 0.14 \mathrm{ng} /$ $\mathrm{mL}$ ), which had the highest amount, and from group $\mathrm{T}(1.5 \pm 0.14 \mathrm{ng} / \mathrm{mL})$. From d -21 to 21 , a decrease occurred in the GLUT4 protein levels in both groups $\mathrm{T}(\mathrm{d}-21: 1.5 \pm 0.14 \mathrm{ng} / \mathrm{mL} ; \mathrm{d} 21: 0.8 \pm 0.14 \mathrm{ng} / \mathrm{mL})$ and $\mathrm{O}(\mathrm{d}-21: 1.8 \pm 0.14 \mathrm{ng} / \mathrm{mL} ; \mathrm{d} 21: 0.8 \pm 0.14 \mathrm{ng} /$ $\mathrm{mL}$ ). These results demonstrate that in obese cows adipose tissue insulin resistance develops prepartum and is related to reduced GLUT4 protein synthesis. Regarding glucose metabolism, body condition did not affect adipose tissue insulin resistance postpartum.

Key words: insulin receptor, glucose transporter 4, glucose tolerance test, adipose tissue, body condition score

\section{INTRODUCTION}

Transition from pregnancy to lactation is associated with important readjustments in metabolism of dairy cows. Due to the onset of milk synthesis, requirements for energy and nutrients, especially for glucose, increase markedly after calving, leading to negative energy balance (NEB; Bell, 1995). To compensate for the energy and nutrient deficiency, large quantities of fatty acids are mobilized from adipose tissue (AT), which, with concurrent low glucose availability, will support the production of BHB and may lead to the development of ketosis (Oetzel, 2007). Insulin and sensitivity of tissues to insulin play a central role in the adjustment of energy partitioning between tissues and in balancing lipogenesis and lipolysis (Bell and Bauman, 1997). In 
dairy cows, insulin resistance (IR) develops during late pregnancy and represents an important homeorhetic adaptation, canalizing metabolism to use energy, mainly stored in AT, to support body functions and to minimize glucose consumption in peripheral tissues, sparing it for milk synthesis under conditions of nutrient and energy deficiency (Bell, 1995; Salin et al., 2012; De Koster and Opsomer, 2013; Zachut et al., 2013).

In general, insulin activates pathways responsible for energy storage within the body [e.g., glucose uptake, lipogenesis, and glycogenesis (Bell and Bauman, 1997)]. In AT, insulin signal transduction starts with binding insulin to its receptor (INSR). The consequent intracellular cascade, mainly through the PI3K/AKT/mTOR pathway, promotes the expression, translocation, and fusion with cell membrane of insulin-dependent glucose transporters 4, responsible for insulin-induced glucose uptake from blood in adipose and muscle tissue. Therefore, INSR and GLUT4, incorporated in the membrane, represent the start and end of insulin signaling responsible for facilitated cellular glucose uptake (Lewis et al., 2002).

The plane of nutrition as a factor influencing insulin sensitivity (Holtenius et al., 2003; Schoenberg et al., 2012) and insulin signaling (Mann et al., 2016b) in cows has been extensively investigated. Regarding body fat reserves, both suboptimal body condition and overcondition before parturition are associated with poor adaptation in the subsequent lactation, leading to an increased incidence of metabolic disorders such as ketosis and fatty liver (Drackley, 1999; Bobe et al., 2004; Goff, 2006; Roche et al., 2013a,b), impaired fertility (Samarütel et al., 2008a,b; Roche et al., 2009), and more pronounced IR (Holtenius and Holtenius, 2007; Jaakson et al., 2013). According to De Koster and coworkers (De Koster et al., 2015, 2016a), development of IR in overconditioned cows at the end of the dry period is associated rather with glucose than lipid metabolism. However, despite intense research work, and due to differences in experimental conditions, design, and aims, a clear understanding regarding cause-and-effect relationships between the IR and the physiological and metabolic status of cows, as well as understanding about the molecular mechanisms of insulin signaling are still lacking. Moreover, the number of studies characterizing protein expression of INSR and GLUT4 in AT is limited (Mann et al., 2016b). No integrated studies are available describing AT INSR and GLUT4 expression in relation to BCS both at the mRNA and protein levels.

In this study we hypothesized that the development and extent of IR during the transition period, mediated by the expression and function of INSR and GLUT4, are related to the amounts of body fat reserves in the dry period. Therefore, the aim of this study was to examine the effect of BCS during the dry period on the mRNA and protein expressions of INSR and GLUT4 in s.c. AT, in addition to the dynamics of insulin and glucose following intravenous glucose infusion in Holstein dairy cows $21 \mathrm{~d}$ before $(\mathrm{d}-21)$ and after $(\mathrm{d} 21)$ calving.

\section{MATERIALS AND METHODS}

\section{Experimental Design and Animals}

The study was carried out on 42 multiparous Holstein cows on the experimental farm of the Estonian University of Life Sciences, which has a herd size of about 120 cows and with average annual milk production of about 9,200 kg per cow. Cows were indoor housed in freestall barns with rubber mats and sawdust bedding and fed TMR ad libitum. Lactating cows were milked twice a day. Three experimental groups were established and proportionally assigned according to the blocked design with each block consisting of 3 cows over 2 consecutive years on the basis of cows' BCS (Edmonson et al., 1989) $28 \mathrm{~d}$ before expected calving $(\mathrm{d}-28)$ as follows: BCS $\leq 3.0(2.25-3.00$; thin, $\mathbf{T} ; \mathrm{n}=14), \mathrm{BCS}=3.25$ to 3.5 (optimal, $\mathrm{O} ; \mathrm{n}=14$ ), and $\mathrm{BCS} \geq 3.75$ (3.75-4.50; overconditioned, $\mathbf{O C} ; \mathrm{n}=14$ ). Parity distribution was different between groups $\mathrm{T}$ [2nd to 5 th (2.6) parity] and $\mathrm{OC}$ [2nd to 6th (3.7) parity; $P=0.006$ ]; group O [2nd to 6th (3.2) parity] did not differ from other groups. Fortnightly assessment of the potential experimental cows' BCS began at drying off, on an average $54(52-59)$ d before expected calving. Cows with an appropriate BCS, and who had maintained their BCS from drying off until d -28 , were assigned to the study blocks. Such cows were removed from the dry cow barn to the tiestall housing to adjust to the experimental conditions. After calving, from the seventh milking, cows were removed to a freestall barn with attached milking parlor.

The European Council Directive regarding the protection of animals, and the Estonian Animal Protection Act, have been complied with in this experiment. The study has been approved by the Committee for Conducting Animal Experiments at the Estonian Ministry of Agriculture.

\section{Feeds and Feeding}

Cows were fed grass silage, hay, corn meal, barley meal, heat-treated rapeseed cake, and mineral feeds as TMR twice daily ad libitum around 0530 and $1430 \mathrm{~h}$. Depending on physiological stage and requirements, cows were fed 5 rations differing in chemical composition and nutritive value (Table 1). Rations were calcu- 
lated according to Estonian feeding recommendations: ME according to Oll (1995), MP on the basis of equations used in Finland (Tuori et al., 1996), modified to suit Estonian conditions as described by Kärt et al. (2002). At drying off, cows were moved into a dry cow barn and offered a far-off dry cow diet containing 8.7 MJ of ME and $73 \mathrm{~g}$ of MP $/ \mathrm{kg}$ of DM. The same diet was continued to be fed after moving the cows into the tiestall barn and entering the study, from $\mathrm{d}-28$ until $\mathrm{d}$ -15 . From d -14 until calving, a close-up dry cow diet containing $10.1 \mathrm{MJ}$ of $\mathrm{ME}$ and $87 \mathrm{~g}$ of $\mathrm{MP} / \mathrm{kg}$ of $\mathrm{DM}$ was fed. After calving, until d 6 of lactation, lactation diet 1 was provided, which differed from the close-up diet only in its mineral composition. From d 7 until d 14 lactation diet 2, with an ME content of $10.9 \mathrm{MJ}$ and MP content of $98 \mathrm{~g}$ per $\mathrm{kg}$ of DM was offered. Lactation diet 3, fed from d 15 onward, containing 11.3 MJ of ME and $104 \mathrm{~g}$ of MP per $\mathrm{kg}$ of DM.

\section{Feed Sampling and Analyses}

The feeding data given in Table 1 represent means for the whole 2-yr study period. Silage samples were taken twice weekly. Other feeds were sampled on a batch basis. All samples were analyzed for DM, whereas chemical composition was analyzed using methods approved by the AOAC (2005) and nutritive value (ME, MP) was calculated once weekly for silage samples, or on the batch basis for other feeds. If necessary, the proportions of the rations' ingredients were corrected to meet required composition and nutritive values.

\section{Milk Sampling and Analyses, Calculation of ECM Yield, and Energy Balance}

The cows were milked twice daily at 0500 and 1500 h. Milk yields were recorded electronically at each milking, using DeLaval's Alpro software for Windows in a DeLaval milking parlor (DeLaval, Tumba, Sweden). Morning and evening milk samples were collected on Sundays and Thursdays from March 2013 to April 2014 using in-line milk meters (MM27BC, DeLaval) and in addition to these days, samples were also collected on Tuesdays from May 2014 to December 2015. Samples from 2 consecutive milkings were pooled per cow. One milk aliquot $(40 \mathrm{~mL})$ of each pooled milk sample was stabilized with bronopol (Broad Spectrum Microtabs, D\&F Control Systems Inc., Norwood, MA) and was analyzed for fat, protein, and lactose contents with an automatic infrared milk analyzer (System FT+, Foss Electric, Hillerød, Denmark) in the Milk Analysis Laboratory of Estonian Livestock Performance Recording Ltd. The ECM yields were calculated according to the method described by Saunja et al. (1991). The following characteristics were calculated for ECM, milk fat, protein, and lactose: yields $(\mathrm{kg})$ and contents (\%) for fat, protein, and lactose on d 21; yields $(\mathrm{kg} / \mathrm{d})$ and contents (\%) for fat, protein, and lactose up to d 21 ; and yields (kg) up to d 21. Starting from the seventh milking, after removal to a freestall barn with attached milking parlor, the cows were weighed twice per day. The average BW of the BSC groups on d 5, after removal to a freestall barn, was as follows: T, $610 \pm 48.0$; $\mathrm{O}, 669 \pm 87.2$; and $\mathrm{OC}, 728 \pm 92.2 \mathrm{~kg}$. The energy balance of the cows was estimated based on effective energy system (Emmans, 1994) and frequent BW measurements and BCS according to Thorup et al. (2012). To characterize cows' energy status, energy balance on d $21(\mathrm{MJ} / \mathrm{d})$ and from parturition to d $21(\mathrm{MJ} / \mathrm{d})$, total energy deficit from parturition to d 21 (MJ), and nadir of NEB (MJ) were calculated (Table 2).

\section{Blood Sampling, Glucose Tolerance Test, and Laboratory Analyses}

Blood samples for metabolic profiling were taken on $\mathrm{d}-21 \pm 0.6$ and $\mathrm{d} 21 \pm 0.2$ at around $1000 \mathrm{~h}$ before AT biopsy and glucose tolerance test (GTT), from the coccygeal vein, and collected into sterile vacuum tubes with Li-heparin (Vacuette, Greiner Bio-One International $\mathrm{GmbH}$, Kremsmünster, Austria) and kept at $+4^{\circ} \mathrm{C}$. Plasma was separated by centrifugation $(5,000 \times$ g, $15 \mathrm{~min},+4^{\circ} \mathrm{C}$ ) within $4 \mathrm{~h}$ after sampling, and stored at $-80^{\circ} \mathrm{C}$ until analysis. Insulin was analyzed by bovineoptimized sandwich ELISA (catalog no. 10-1201-01; Mercodia AB, Uppsala, Sweden), with the detection limit of $0.025 \mathrm{ng} / \mathrm{mL}$, on microplate reader (Sunrise, Tecan Group Ltd., Männedorf, Switzerland); results were calculated using cubic spline regression (Magellan data analysis software; Tecan Group Ltd.). To ensure consistency of the results low $(5.1 \mu \mathrm{U} / \mathrm{mL})$ and high $(41.1 \mu \mathrm{U} / \mathrm{mL})$, control samples for insulin measurement were prepared by pooling plasmas from 4 cows with low and from 4 cows with high insulin concentrations, respectively. Interassay coefficients of variation (CV) were determined by analyzing the low and high control samples in 6 ELISA plates in duplicate. For determination of intraassay $\mathrm{CV}$, the control samples were run in 6 replicates in duplicate in 1 ELISA plate. The interassay CV for low and high control samples were 4.6 and $6.6 \%$, respectively; the intraassay CV were 4.2 and $4.1 \%$, respectively. Glucose was analyzed by enzymatic-colorimetric method (product code XSYS 012, ERBA Diagnostics Mannheim GmbH, Germany), fatty acids by enzymatic-colorimetric method (catalog no. FA 115, Randox Laboratories Ltd., Crumlin, UK) and BHB by kinetic-enzymatic UV-method (catalog no. RB 1007; Randox Laboratories Ltd.) on an auto- 
Table 1. Feed ingredients and chemical composition (mean $\pm \mathrm{SD}$ ) of TMR $(\mathrm{g} / \mathrm{kg})$ fed to experimental cows

\begin{tabular}{|c|c|c|c|c|c|}
\hline \multirow[b]{2}{*}{ Item } & \multicolumn{5}{|c|}{ Ration } \\
\hline & Far-off dry cow & $\begin{array}{l}\text { Close-up } \\
\text { dry cow }\end{array}$ & $\begin{array}{l}\text { Lactation diet } 1 \\
\text { from calving till d } 6\end{array}$ & $\begin{array}{l}\text { Lactation diet } 2 \\
\text { from d } 7 \text { to } 14\end{array}$ & $\begin{array}{l}\text { Lactation diet } \\
3 \text { from d } 15\end{array}$ \\
\hline Grass silage & $955 \pm 81$ & $599 \pm 71$ & $604 \pm 72$ & $460 \pm 49$ & $384 \pm 37$ \\
\hline Hay & $33.6 \pm 81$ & $28.3 \pm 69$ & $28.6 \pm 70$ & $20.3 \pm 49$ & $15.6 \pm 37$ \\
\hline Barley meal & - & $301 \pm 10$ & $303 \pm 10$ & $309 \pm 0.1$ & $296 \pm 0.2$ \\
\hline Mineral-vitamin feed & $11.7 \pm 0.1^{1}$ & $7.82 \pm 0.2^{1}$ & $10.5 \pm 0.3^{2}$ & $8.58 \pm 0.0^{2}$ & $7.99 \pm 0.0^{2}$ \\
\hline Anionic mineral feed ${ }^{3}$ & - & $10.4 \pm 0.2$ & - & - & - \\
\hline Limestone & - & $6.26 \pm 0.2$ & - & $4.29 \pm 0.0$ & $4.41 \pm 0.7$ \\
\hline Sodium chloride & - & - & $5.78 \pm 0.1$ & $4.72 \pm 0.0$ & $4.40 \pm 0.0$ \\
\hline \multirow{2}{*}{\multicolumn{6}{|c|}{ Chemical composition in DM }} \\
\hline & & & & & \\
\hline $\mathrm{OM}$ & $893 \pm 9.0$ & $904 \pm 5.9$ & $911 \pm 6.0$ & $918 \pm 4.5$ & $923 \pm 3.9$ \\
\hline Crude fiber & $285 \pm 24$ & $198 \pm 15$ & $200 \pm 15$ & $171 \pm 13$ & $153 \pm 11$ \\
\hline NDF & $534 \pm 51$ & $455 \pm 32$ & $458 \pm 32$ & $410 \pm 25$ & $380 \pm 22$ \\
\hline $\mathrm{ADF}$ & $387 \pm 47$ & $278 \pm 29$ & $280 \pm 29$ & $242 \pm 22$ & $220 \pm 18$ \\
\hline Calcium & $11.4 \pm 1.9$ & $10.3 \pm 1.3$ & $9.33 \pm 1.3$ & $9.54 \pm 1.0$ & $8.97 \pm 0.8$ \\
\hline Phosphorus & $3.42 \pm 0.4$ & $4.06 \pm 0.2$ & $4.03 \pm 0.2$ & $4.48 \pm 0.2$ & $4.77 \pm 0.2$ \\
\hline
\end{tabular}

${ }^{1}$ Composition (as-fed basis): $170 \mathrm{~g} / \mathrm{kg}$ of Ca; $50 \mathrm{~g} / \mathrm{kg}$ of P; $30 \mathrm{~g} / \mathrm{kg}$ of Na; $140 \mathrm{~g} / \mathrm{kg}$ of Mg; $30 \mathrm{~g} / \mathrm{kg}$ of S; 1,000 mg/kg of Cu; 4,500 mg/kg of $\mathrm{Zn} ; 4,000 \mathrm{mg} / \mathrm{kg}$ of $\mathrm{Mn} ; 40 \mathrm{mg} / \mathrm{kg}$ of Se; $50 \mathrm{mg}$ of Co; $200 \mathrm{mg}$ of I; 800,000 IU/ $\mathrm{kg}$ of vitamin A; 190,000 IU/ $/ \mathrm{kg}$ of vitamin D; and 8,000 IU/kg of vitamin E.

${ }^{2}$ Composition (as-fed basis): $150 \mathrm{~g} / \mathrm{kg}$ of Ca, $35 \mathrm{~g} / \mathrm{kg}$ of P, $75 \mathrm{~g} / \mathrm{kg}$ of Na, $90 \mathrm{~g} / \mathrm{kg}$ of Mg, $1 \mathrm{~g} / \mathrm{kg}$ of S, $4,000 \mathrm{mg} / \mathrm{kg}$ of Cu, 6,667 mg/kg of Zn, $6,452 \mathrm{mg} / \mathrm{kg}$ of Mn, $94 \mathrm{mg} / \mathrm{kg}$ of Se, $109 \mathrm{mg}$ of Co, 650,000 IU $/ \mathrm{kg}$ of vitamin A, 150,000 IU $/ \mathrm{kg}$ of vitamin D, and 4,000 IU/ $/ \mathrm{kg}$ of vitamin E.

${ }^{3}$ Composition (as-fed basis): $9 \mathrm{~g} / \mathrm{kg}$ of Ca, $1 \mathrm{~g} / \mathrm{kg}$ of P, $5 \mathrm{~g} / \mathrm{kg}$ of Na, $100 \mathrm{~g} / \mathrm{kg}$ of $\mathrm{Mg}, 1,000 \mathrm{mg} / \mathrm{kg} \mathrm{of} \mathrm{Cu,} 5,000 \mathrm{mg} / \mathrm{kg}$ of Zn, 2,000 mg/kg of $\mathrm{Mn}, 27 \mathrm{mg} / \mathrm{kg}$ of Se, $40 \mathrm{mg}$ of Co, $100 \mathrm{mg}$ of I, 1,000,000 IU/ $/ \mathrm{kg}$ of vitamin A, 60,000 IU/ $\mathrm{kg}$ of vitamin D, and 10,000 mg/kg of vitamin E, and $100,000 \mu \mathrm{g} / \mathrm{kg}$ of biotin.

Table 2. Least squares means with pooled SEM for BCS, energy balance (EB), and milk production characteristics in experimental groups

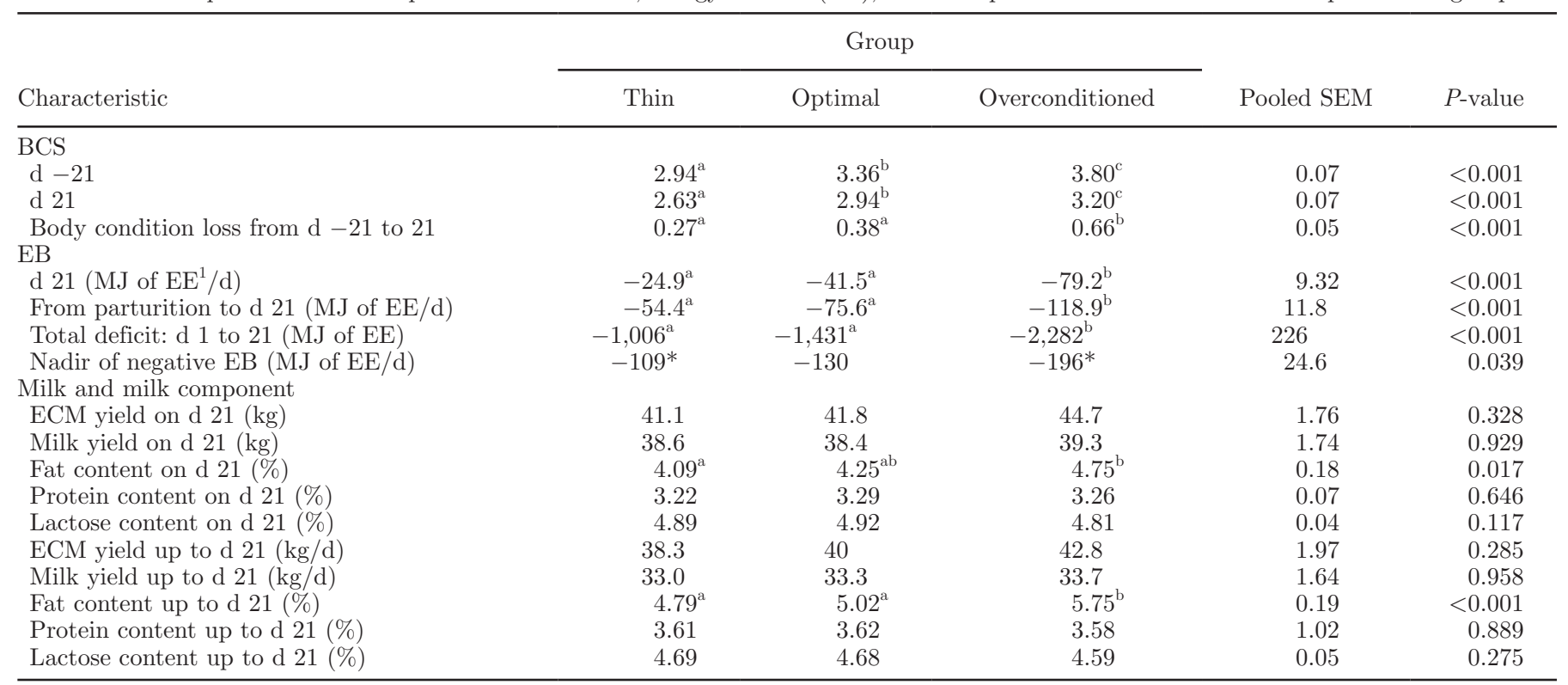

${ }^{\mathrm{a}-\mathrm{C}} \mathrm{LSM}$ with different letters within a row $\operatorname{differ}(P \leq 0.05)$.

${ }^{1} \mathrm{EE}=$ ether extract.

*LSM with asterisk within a row tend to differ $(P \leq 0.1)$. 
matic analyzer (ERBA XL300, Randox Laboratories Ltd.). For glucose, fatty acids, and BHB, intraassay CV were determined by analyzing plasma in 20 replicates in 3 duplicates; interassay $\mathrm{CV}$ were calculated on the basis of 3 duplicates. The interassay CV were $4.8,8.3$, and $6.1 \%$, and intraassay CV 4.9, 6.1, and $5.7 \%$ for glucose, fatty acids, and BHB, respectively. For quality assessment, control serum samples (for glucose: ERBA NORM, catalog no. BLT00080, ERBA Diagnostics Mannheim GmbH; for fatty acids and BHB: BOV ASY CONTROL 2, product code AN 1026, Randox Laboratories Ltd.) were run routinely.

The GTT was carried out at around $1000 \mathrm{~h}$ after collection of AT samples (see below). Cows were deprived from feed approximately $1 \mathrm{~h}$ before and during the GTT. A catheter was inserted into the jugular vein and fixed to the skin $30 \mathrm{~min}$ before the test. The catheter was filled with saline dilution of Li-heparin until the start and between blood samplings to avoid clotting. After infusion of a $0.15 \mathrm{~g} / \mathrm{kg}$ of BW glucose bolus (40\% solution), the tubing and catheter were flushed with normal saline. Discarding the first portion, blood samples were collected at the following time points: -5 (basal), 5, 10, 20, 30, 40, 50, and 60 min relative to the start of infusion. Plasma was separated and stored at $-80^{\circ} \mathrm{C}$ until analyzed for glucose as described above, and insulin was analyzed using RIA as described earlier by Vicari et al. (2008). The intra- and interassay CV for insulin were both $<10 \%$. The following characteristics were calculated to describe glucose and insulin responses to the GTT: increment $(\mathrm{mg} / \mathrm{dL})$, area under the curve 5-20,5-30, and 5-60 $\mathrm{min}(\mathrm{mg} / \mathrm{dL} \times \min )$ and reversion time (time to reach basal concentration, $\left.\mathrm{T}_{\text {basal }} ; \mathrm{min}\right)$ for glucose and insulin; clearance rate (CR; $\% / \mathrm{min})$ and half-time $\left(\mathrm{T}_{1 / 2} ; \mathrm{min}\right)$ for glucose. Increment was calculated as the difference between the maximum and basal concentration. The areas under the curve describe incremental area (Cardoso et al., 2011) and were calculated as the definite integral of the fifth-order polynomial. For the calculation of $\mathrm{CR}, \mathrm{T}_{1 / 2}$ and $\mathrm{T}_{\text {basal }}$ exponential curves were fitted. Following formulas, described by Kaneko et al. (2008), where $x$ is the concentration of glucose corrected for baseline concentration at a given time point and $t$ is time, were used:

$$
\begin{gathered}
\mathrm{CR}=\frac{\ln \left(x_{t 10}\right)-\ln \left(x_{t 40}\right)}{t_{10}-t_{40}} \times 100, \\
\mathrm{~T}_{\frac{1}{2}}=\frac{\ln (2)}{\mathrm{CR}} \times 100 .
\end{gathered}
$$

For the calculation of $\mathrm{T}_{\text {basal }}$, the following formula, where $x$ is the concentration of glucose or insulin at a given time point, was used:

$$
\mathrm{T}_{\text {basal }}=\frac{t_{40}-t_{10}}{\ln \left(x_{t 10}\right)-\ln \left(x_{t 40}\right)} \times 100
$$

\section{Adipose Tissue Biopsies}

Subcutaneous AT biopsies were taken after blood sampling for metabolic profiling and before the GTT on $\mathrm{d}-21 \pm 0.6$ and $\mathrm{d} 21 \pm 0.2$ at around $1000 \mathrm{~h}$ from alternate sides of the body from the pin bone region after local anesthesia with lidocaine hydrochloride (Lidocaine-Grindex $20 \mathrm{mg} / \mathrm{mL}$ injection solution) under aseptic conditions. Ten minutes after injection of lidocaine hydrochloride, a 2-cm skin incision was made and a tissue sample of about $3 \mathrm{~g}$ was collected. Samples were flushed with sterile physiological saline to remove excess of blood and were split into 0.5 -g portions onto a sterile Petri dish, mounted into screw-cap tubes (Axygen, Corning Inc., Corning, NY), immediately frozen in liquid nitrogen, and stored at $-80^{\circ} \mathrm{C}$ until analysis. The skin incision was closed with stitches and the wound was covered with an oxytetracycline spray for disinfection and an aluminum spray for mechanical protection.

\section{Processing of Adipose Tissue and Measuring INSR and GLUT4 mRNA Expression}

Adipose tissue $(100 \mathrm{mg})$ disruption and homogenization was achieved using the FastPrep-24 (116004500 MP Biomedicals, Illkirch-Graffenstaden, France) for 30 $\mathrm{s}$ at $6.5 \mathrm{~m} / \mathrm{s}$ with a Metal Bead Lysing Matrix (catalog no. 6925-050) in $1 \mathrm{~mL}$ of QIAzol Lysis Reagent (catalog no. 79306, Qiagen GmbH, Hilden, Germany). Total RNA was isolated from homogenized tissue with the RNeasy Lipid Tissue Mini Kit (catalog no. 74804, Qiagen $\mathrm{GmbH}$ ) following the manufacturer's recommendations. Isolated total RNA integrity was determined using a 2100 Bioanalyzer (Agilent Technologies, Massy, France) and RNA 6000 Nano kit (Agilent Technologies Inc., Santa Clara, CA); RNA integrity was found to range between 6.7 and 8.0. The RNA concentrations were determined with the Qubit RNA HS Assay Kit (catalog no. Q32852). Total RNA extracted from tissues was stored at $-80^{\circ} \mathrm{C}$. For cDNA synthesis, 100 to $250 \mathrm{ng}$ of total RNA was reverse transcribed using the QuantiTect Reverse Transcription Kit (catalog no. 205311, Qiagen $\mathrm{GmbH}$ ) following the manufacturer's instructions; synthesized cDNA was stored at $-20^{\circ} \mathrm{C}$. Sample cDNA was used for multiplex quantitative realtime PCR using one 384-well plate for each target gene together with reference gene in 4 replicates. Quantitative real-time PCR was performed using the TaqMan Gene Expression Master Mix (catalog no. 4369016, Thermo Fisher Scientific Inc., Waltham, MA) with the 
ViiA 7 Real-Time PCR System (Applied Biosystems, Waltham, MA). Primers and probes were purchased from Applied Biosystems.

GADPH (forward primer sequence: GGCGTGAACCACGAGAAGTATAA, reverse primer sequence: CCCTCCACGATGCCAAAGT, probe sequence: ATACCCTCAAGATTGTCAGCAATGCCTCCT) was used as a reference gene for normalization of mRNA expression levels of the INSR (forward primer sequence: TCCTCAAGGAGCTGGAGGAGT, reverse primer sequence: GCTGCTGTCACATTCCCCA, probe sequence: ATCATCTTCAGGCCCTGTTGCCGAG) and SLC24A (GLUT4; Assay ID: Bt03215323_m1, Thermo Fisher Scientific Inc.) genes. Cycle threshold $(\mathbf{C t})$ values were used to calculate the relative gene expression level using the $\Delta \mathrm{Ct}$ method. For statistical analysis, 4-replicate means of $\mathrm{Ct}$ values were used; for 3 samples, regarding $I N S R$, and for 11 samples, regarding SLC24A (GLUT4), 3-replicate means were used due to undetected levels of mRNA.

\section{Processing of Adipose Tissue and Measuring INSR and GLUT4 Protein Expression}

Approximately 20 to $200 \mathrm{mg}$ of lipid tissue biopsy was homogenized using the FastPrep-24 (116004500 MP Biomedicals, France) and Lysing Matrix D 2-mL tubes (catalog no. 116913100, MP Biomedicals, LLC, Santa Ana, CA). Prior to homogenizing, the tissue was washed in $1 \mathrm{~mL}$ PBS and transferred to a homogenizing tube containing $1 \mathrm{~mL}$ of homogenizing solution. The homogenizing solution was based on PBS with a proteinase inhibitor (Complete Ultra Tablets, catalog no. 05892791001, Roche Diagnostics, Indianapolis, IN). The FastPrep-24 Instrument program was as follows: 2 $\times 30 \mathrm{~min}$ with a speed of $6.5 \mathrm{~m} / \mathrm{s}$. Dry ice was used for cooling during homogenization. The homogenate was transferred into a new tube and centrifuged at room temperature at $1,000 \times g$ for $10 \mathrm{~min}$. The clear homogenate below the upper fat layer was transferred into a new tube. The clear homogenate was used for total protein and target protein concentration measurements. Concentration of target protein was normalized to total protein concentration. The total protein concentration was measured applying the Modified Lowry Protein Assay Kit (catalog no. 23240, Thermo Fischer Scientific Inc., Waltham, MA) according to the manufacturer's protocol in 3 replicates. An amount of 50 to $150 \mu \mathrm{g}$ of total protein was used for each ELISA reaction. The samples were measured in 2 replicates and means were used for data analysis. For ELISA, commercial kits were used according to the manufacturer's protocol (INSR: catalog no. E11A0445, GLUT4: catalog no. E11G0201, Antibodies-Online Inc., Dunwoody, GA). Inter- and intra-assay $\mathrm{CV}$, provided by the kit's manufacturer, were 7.9 and $5.6 \%$ both for INSR and GLUT4.

\section{Statistical Analysis}

Before statistical analysis, the continuous energy balance and milk production data were condensed to means on d 21 and up to d 21 and the relative concentrations of INSR and GLUT4 mRNA were multiplied by 1,000 and 100, respectively, to avoid negative values after logarithmic transformation. Statistical analyses were performed with the software $\mathrm{R}$ (version 3.3.1, R Foundation for Statistical Computing, Vienna, Austria). To estimate the effect of BCS group and time period on the study variables, the mixed linear model was fitted, considering the fixed effects of BCS group, time, and their interaction, parity, presence of health disorders, relative breeding value for milk production as covariate and random effects of block and cow nested to block. The latter 2 effects allow for consideration of the potential similarity of cows in the same triplet, and repeated measurements of the same cow before and after parturition. For variables measured only after parturition and for GTT characteristics after parturition, the effects of time, interaction between time and BCS group, and cow were excluded from the model. For GTT characteristics before parturition, the presence of health disorders was further excluded. The modeling was performed with the function "lmer" in the package "lme4" and the least squares means (LSM, alias marginal or model-based means) were estimated with the function "Ismeans." The pairwise comparison of LSM in BCS groups was performed with the function "contrast," and $P$-values were adjusted for multiple testing with the Tukey method. For nonnormally distributed variables, 2 analyses were performed: at first the models were fitted and the LSM were estimated on an actual scale and subsequently the $P$-values were estimated fitting the same models on logarithm-transformed variables. Statistical significance was declared at $P \leq 0.05$ and trend at $P \leq 0.1$.

\section{RESULTS}

\section{Health Events, BCS, Energy Balance, and Milk Production}

All cows were clinically healthy during the prepartum experimental period. Postpartum, up to d 21 the following health events occurred: dystocia (1 case in group T, 2 cases in group OC), retained placenta (1 case in group $\mathrm{OC})$, metritis ( 1 case in groups $\mathrm{O}$ and OC), mastitis ( 3 cases in group T, 2 cases in groups $\mathrm{O}$ and $\mathrm{OC}$ ), lameness (2 cases in group $\mathrm{O}, 1$ case in 
group OC), and hypocalcemia ( 1 case in groups $\mathrm{T}, \mathrm{O}$, and $\mathrm{OC})$.

The BCS, NEB, and milk production characteristics of experimental groups are presented in Table 2. The BCS differed between all groups on $\mathrm{d}-21(P<0.001)$ and $\mathrm{d} 21$ ( $\mathrm{T}$ vs. $\mathrm{O}, P=0.006$; T vs. $\mathrm{OC}, P=0.001$; $\mathrm{O}$ vs. OC, $P=0.026$ ), being lowest in group $\mathrm{T}$ and highest in group OC at both selected time points. The OC cows also showed greater body condition loss compared with group $\mathrm{T}$ and $\mathrm{O}$ cows $(P<0.001$, Table 2$)$. Among calculated NEB characteristics, energy balance on d 21 and energy balance from parturition to d 21 per day were more negative, and the total deficit from parturition to d 21 was biggest, in group OC compared with groups $\mathrm{T}(P<0.001 ; P=0.001 ; P<0.001$, respectively $)$ and $\mathrm{O}(P=0.011 ; P=0.023 ; P=0.020$, respectively). The depth of the NEB nadir tended to differ between the group $\mathrm{T}$ with the least and group OC with the deepest nadir $(P=0.058$, Table 2$)$. Differences between the groups' ECM and milk yields on d 21 and yields per day were not significant. Milk fat content on d 21 differed between the group OC, with the highest, and group $\mathrm{T}$, with the lowest, fat contents $(P=0.031)$, whereas milk fat yields between these groups tended to differ $(P=0.052)$. Mean milk fat content during the first $21 \mathrm{~d}$ of lactation was highest in group OC, differing from group $\mathrm{O}$ with intermediate $(P=0.019)$ and group $\mathrm{T}$ with the lowest fat contents $(P=0.003)$. None of the measured and calculated characteristics for milk protein and lactose content or milk production were different between the groups (Table 2).

\section{Glucose Tolerance Test and Blood Metabolite Concentrations}

Response curves for glucose and insulin during the GTT are presented in Figure 1, and calculated GTT characteristics and measured blood metabolite concentrations are given in Table 3. The basal concentrations of blood glucose before glucose infusion on $\mathrm{d}-21$ did not differ between the groups $(\mathrm{T}, 92.7 \pm 2.05 \mathrm{mg} / \mathrm{dL}$; $\mathrm{O}, 95.7 \pm 1.98 \mathrm{mg} / \mathrm{dL} ; \mathrm{OC}, 96.6 \pm 2.05 \mathrm{mg} / \mathrm{dL})$. After glucose infusion, blood glucose concentration increased rapidly, becoming maximum at $5 \mathrm{~min}$ in all groups. The maximum was lowest in group $\mathrm{T}(228.8 \pm 7.20 \mathrm{mg} / \mathrm{dL})$, which tended to differ from group $\mathrm{O}$ with an intermediate level $(251.3 \pm 6.96 \mathrm{mg} / \mathrm{dL}, P=0.085)$ and differed from group OC with the highest maximum (259.7 \pm $7.20 \mathrm{mg} / \mathrm{dL}, P=0.019)$. All of the groups differed at 10 min (T vs. $\mathrm{O}, P=0.013$; $\mathrm{T}$ vs. $\mathrm{OC}, P<0.001$; $\mathrm{O}$ vs. OC, $P=0.033)$; the concentration was still the lowest in group $\mathrm{T}(200.9 \pm 2.97)$, intermediate in group $\mathrm{O}(213.8 \pm 2.87)$, and the highest in group OC (225.1 \pm 2.97 ). At 20 min postinfusion glucose concentration in group $\mathrm{T}$ remained the lowest (167.9 $\pm 3.15 \mathrm{mg} /$ $\mathrm{dL}$ ) and differed from group $\mathrm{O}$ with the intermediate level $(179.0 \pm 3.04 \mathrm{mg} / \mathrm{dL}, P=0.049)$ and from group OC with the highest level $(184.6 \pm 3.15 \mathrm{mg} / \mathrm{dL}, P=$ 0.004). From 20 min onward, differences between the groups disappeared, the blood glucose concentration continually decreased in all groups. However, at $60 \mathrm{~min}$ the preinfusion level had still not been reached (Figure 1). Among calculated GTT characteristics for glucose, the lowest increment in group $\mathrm{T}$ was different from the highest increment in group OC $(P=0.022)$. The area under the curve (AUC) of glucose was the smallest in group $\mathrm{T}$ and largest in group OC. Group $\mathrm{O}$ had an intermediate value (Table 3); AUC of glucose 5-20 min was different between all groups ( $\mathrm{T}$ vs. $\mathrm{O}, P=0.012$; T vs. OC. $P<0.001 ; \mathrm{O}$ vs. OC, $P=0.029)$, AUC $5-30$ min in group $\mathrm{T}$ was different from group $\mathrm{O}(P=0.028)$ and OC $(P<0.001)$, and AUC 5-60 min did not differ between groups (Table 3 ).

The amplitude of glucose response following glucose infusion on d 21 postpartum was less pronounced compared with d -21 prepartum (Figure 1, Table 3). Starting from the basal level $(\mathrm{T}, 84.9 \pm 3.27 \mathrm{mg} / \mathrm{dL}$; $\mathrm{O}, 87.6 \pm 3.24 \mathrm{mg} / \mathrm{dL} ;$ OC, $85.4 \pm 3.28 \mathrm{mg} / \mathrm{dL}$ ), blood glucose concentration increased to a maximum at $5 \mathrm{~min}$ in all groups $(\mathrm{T}, 200.9 \pm 3.68 \mathrm{mg} / \mathrm{dL} ; \mathrm{O}, 206.6 \pm 3.65$ $\mathrm{mg} / \mathrm{dL}$; OC, $212.5 \pm 3.69 \mathrm{mg} / \mathrm{dL}$ ) and from this point onward gradually decreased (Figure 1). No significant differences were observed between the groups for blood glucose concentrations at any time point (Figure 1). Among calculated GTT characteristics highest glucose increment in group OC differed from lowest increment in group $\mathrm{T}(P=0.007)$; no significant differences were found between the groups for other calculated GTT characteristics (Table 3).

Blood insulin pre-infusion basal concentration on d -21 was the lowest in group $\mathrm{T}(13.9 \pm 2.32 \mu \mathrm{U} / \mathrm{mL})$, different from group OC, which had the highest blood insulin level $(24.3 \pm 2.32 \mu \mathrm{U} / \mathrm{mL}, P=0.008)$. Group $\mathrm{O}$, with an intermediate insulin basal level $(17.7 \pm 2.25$ $\mu \mathrm{U} / \mathrm{mL}$ ), was not different from the other groups. The subsequent increase of blood insulin was modest in group T. The maximum level $(169.8 \pm 33.3 \mu \mathrm{U} / \mathrm{mL})$ in this group was achieved at 10 min followed by a decrease from that time point onward. In groups $\mathrm{O}$ and OC blood insulin concentration continued to increase up to 20 min postinfusion, giving rise to differences at this time point between group $\mathrm{T}$, with the lowest (167.4 $\pm 33.9 \mu \mathrm{U} / \mathrm{mL}$ ), and group OC, with the highest insulin level $(317.2 \pm 33.9 \mu \mathrm{U} / \mathrm{mL}, P=0.026)$. Differences between group $\mathrm{O}$ and other groups were not significant. Subsequently, in all groups, blood insulin concentration gradually decreased, whereas differences between group $\mathrm{T}$ with the lowest insulin concentrations and group OC 

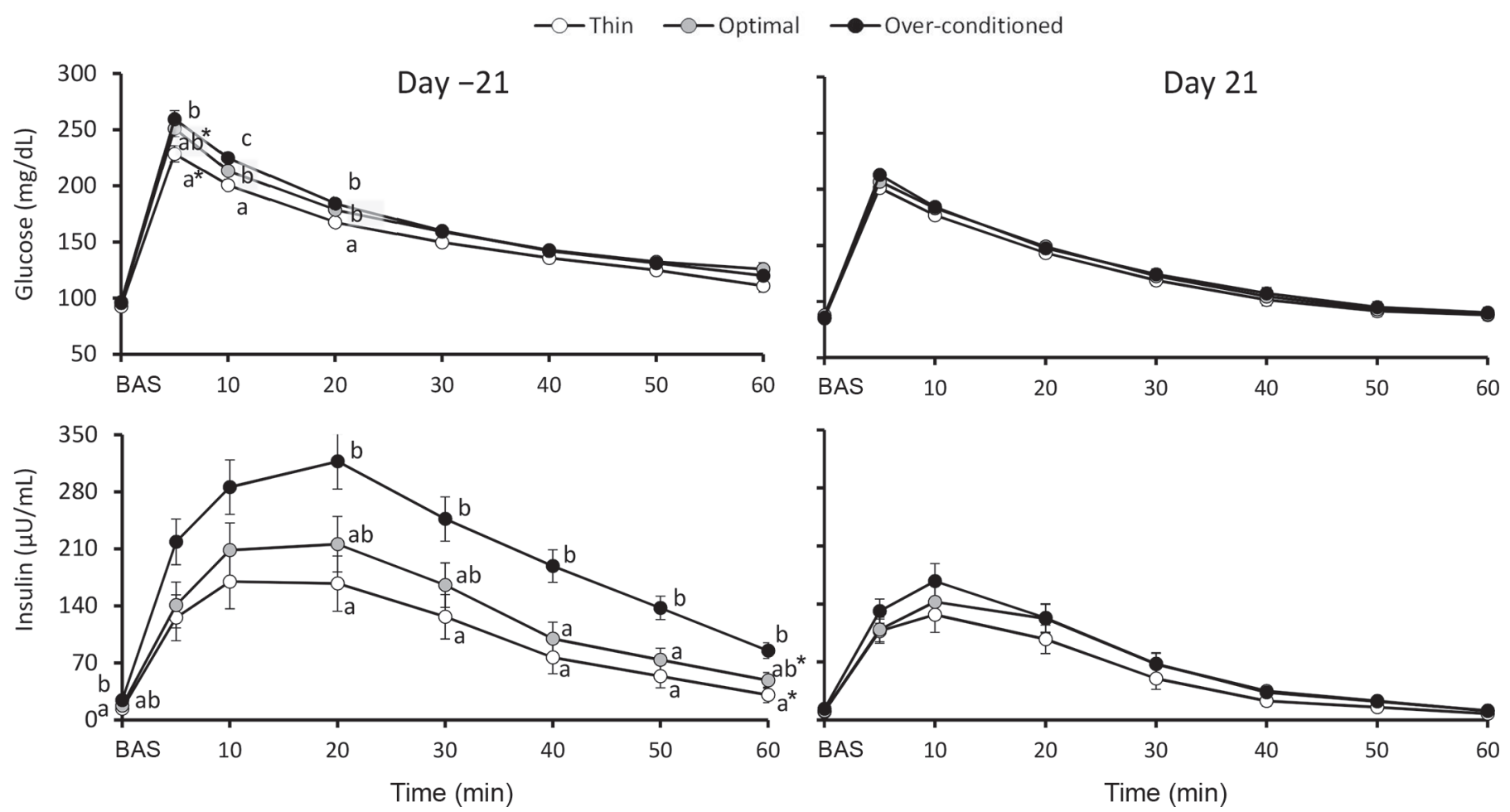

Figure 1. Basal concentrations (BAS) and dynamics for blood glucose (upper panels) and insulin (lower panels) during the i.v. glucose tolerance test (GTT) $21 \mathrm{~d}$ before $(\mathrm{d}-21$, left panel) and $21 \mathrm{~d}$ after calving (d 21, right panel) in multiparous Holstein dairy cows $(\mathrm{n}=42,14$ in each group) grouped according to BCS 4 wk before calving as follows: BCS $\leq 3.0$ (thin; T); BCS $=3.25-3.5$ (optimal; O); and BCS $\geq 3.75$ (overconditioned; OC). Different letters $(\mathrm{a}-\mathrm{c})$ indicate significant differences between the groups $(P \leq 0.05)$ at certain time points, means with asterisks $\left(^{*}\right)$ indicate a tendency to differ $(P \leq 0.1)$. Error bars represent SEM.

with the highest concentrations persisted up to $60 \mathrm{~min}$ postinfusion. In addition, group $\mathrm{O}$ differed from group $\mathrm{OC}$ at $40 \min (99.8 \pm 19.4$ vs. $188.9 \pm 20.1 \mu \mathrm{U} / \mathrm{mL}, P$ $=0.018)$, at $50 \mathrm{~min}(73.7 \pm 13.8$ vs. $137.6 \pm 14.3 \mu \mathrm{U} /$ $\mathrm{mL}, P=0.020)$ and tended to differ at $60 \mathrm{~min}$ postinfusion. At $60 \mathrm{~min}$ the pre-infusion level of blood insulin had still not been achieved, being lowest in group $\mathrm{T}$ $(32.2 \pm 6.9 \mu \mathrm{U} / \mathrm{mL})$, differing from group OC with the highest insulin concentration $(82.9 \pm 6.9 \mu \mathrm{U} / \mathrm{mL}$, $P=0.001$ ), and tending to differ from group $\mathrm{O}$ with the intermediate insulin concentration $(51.9 \pm 6.9 \mu \mathrm{U} /$ $\mathrm{mL}, P=0.070$, Figure 1). Regarding calculated GTT characteristics, the lowest increment of blood insulin in group $\mathrm{T}$ differed from group $\mathrm{OC}$ with the highest increment $(P=0.031)$. The smallest AUC $5-60$ in group T differed from the largest AUC in group OC $(P=0.021)$, and reversion time (time to reach basal concentration) in group OC was longer compared with both group $\mathrm{T}$ $(P=0.005)$ and group $\mathrm{O}(P=0.011$, Table 3$)$.

Pre-infusion blood insulin basal concentration ( $\mathrm{T}$, $9.6 \pm 2.26 \mu \mathrm{U} / \mathrm{mL} ; \mathrm{O}, 10.5 \pm 2.24 \mu \mathrm{U} / \mathrm{mL} ; \mathrm{OC}, 13.5$ $\pm 2.27 \mu \mathrm{U} / \mathrm{mL}$ ) was lower, and the extent of insulin response during the GTT on d 21, was less pronounced compared with $\mathrm{d}-21$ in all groups. The peak of insulin appeared at $10 \mathrm{~min}$ in all groups $(\mathrm{T}, 127.0 \pm 21.3 \mu \mathrm{U} /$ $\mathrm{mL} ; \mathrm{O}, 142.6 \pm 21.1 \mu \mathrm{U} / \mathrm{mL} ; \mathrm{OC}, 167.6 \pm 21.3 \mu \mathrm{U} /$ $\mathrm{mL}$ ) followed by a continuous decrease and stabilization at the basal level at 60 min postinfusion $(\mathrm{T}, 7.6 \pm$ $1.67 \mu \mathrm{U} / \mathrm{mL} ; \mathrm{O}, 10.8 \pm 1.65 \mu \mathrm{U} / \mathrm{mL}$; OC, $11.3 \pm 1.67$ $\mu \mathrm{U} / \mathrm{mL}$; Figure 1). No significant differences between the groups' blood insulin levels were found at any time point during the GTT, though groups $\mathrm{T}$ and $\mathrm{O}$ tended to differ at $40 \mathrm{~min}(P=0.092)$ and $50 \mathrm{~min}(P=0.087)$, or between any of the groups' calculated GTT characteristics (Figure 1, Table 3).

Blood fatty acid concentrations on $\mathrm{d}-21$ did not differ between the groups $(\mathrm{T}, 0.11 \pm 0.08 \mathrm{mmol} / \mathrm{L} ; \mathrm{O}$, $0.07 \pm 0.08 \mathrm{mmol} / \mathrm{L}$; OC, $0.16 \pm 0.08 \mathrm{mmol} / \mathrm{L})$. Compared with $\mathrm{d}-21$, fatty acids were higher on $\mathrm{d} 21$ in all groups $(P<0.001)$ and differed $(P=0.027)$ between the groups $\mathrm{T}$ with lowest $(0.34 \pm 0.08 \mathrm{mmol} / \mathrm{L})$ and OC with highest $(0.62 \pm 0.08 \mathrm{mmol} / \mathrm{L})$ concentration. Group $\mathrm{O}$ with intermediate fatty acid concentration $(0.47 \pm 0.08 \mathrm{mmol} / \mathrm{L})$ did not differ from other groups. Blood BHB concentration did not differ between the groups on $\mathrm{d}-21(\mathrm{~T}, 0.62 \pm 0.12 \mathrm{mmol} / \mathrm{L} ; \mathrm{O}, 0.61$ $\pm 0.12 \mathrm{mmol} / \mathrm{L} ; \mathrm{OC}, 0.55 \pm 0.12 \mathrm{mmol} / \mathrm{L})$ or on $\mathrm{d}$ $21(\mathrm{~T}, 0.56 \pm 0.12 \mathrm{mmol} / \mathrm{L} ; \mathrm{O}, 0.67 \pm 0.12 \mathrm{mmol} / \mathrm{L}$; 
JAAKSON ET AL.

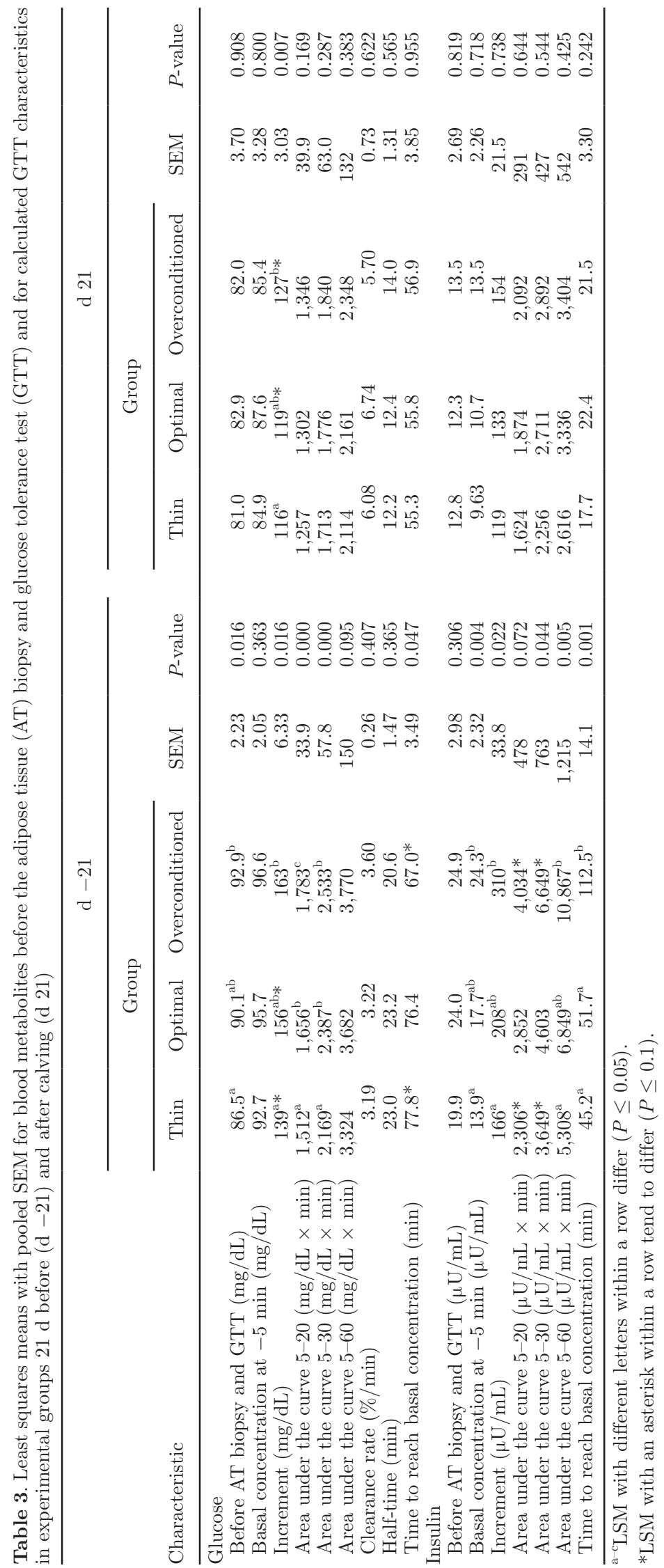


OC, $0.97 \pm 0.12 \mathrm{mmol} / \mathrm{L}$ ); however, in group OC BHB concentration was higher on $\mathrm{d} 21$ compared with $\mathrm{d}-21$ $(P=0.045)$.

\section{Expression of INSR and GLUT4}

Data for AT INSR and GLUT4 expression in the experimental groups are presented in Figure 2. No significant differences in AT INSR mRNA abundances between the groups were evident at $\mathrm{d}-21$ or 21 . However, INSR mRNA abundance on d 21 was higher compared with $\mathrm{d}-21$ in group $\mathrm{T}(3.2 \pm 0.44 ; 5.9 \pm 0.44 ; P<$ $0.001)$ and in group $\mathrm{O}(3.1 \pm 0.44 ; 5.1 \pm 0.44 ; P=$ $0.001)$. The increase of mRNA from $\mathrm{d}-21$ to 21 in group OC was close to a tendency $(3.7 \pm 0.45 ; 4.7 \pm$ $0.45 ; P=0.112)$. The extent of adipose INSR protein expression on $\mathrm{d}-21$ was highest in group $\mathrm{T}(7.3 \pm$ $0.73 \mathrm{ng} / \mathrm{mL}$ ), different from group $\mathrm{O}$, which had the lowest degree of protein expression $(4.6 \pm 0.73 \mathrm{ng} / \mathrm{mL}$; $P=0.040)$. Group OC, with an intermediate protein level $(6.5 \pm 0.74 \mathrm{ng} / \mathrm{mL})$, was not different from either of the other groups. Amounts of AT INSR protein did not change from $\mathrm{d}-21$ to 21 in any of the groups, and significant differences between the groups disappeared on d 21 (Figure 2).

Abundance of AT GLUT4 mRNA on d -21 tended to differ $(P=0.075)$ between group $\mathrm{T}(3.5 \pm 0.35)$, with highest level of mRNA expression, and group $\mathrm{O}$ $(2.4 \pm 0.35)$ with the lowest level, whereas group OC $(2.9 \pm 0.35)$ with intermediate mRNA abundance was not different from the other groups. Compared with d -21 AT GLUT4 mRNA abundance on d 21 remained largely unchanged in group $\mathrm{O}$, whereas a decrease of mRNA occurred in group $\mathrm{T}(P=0.123)$ and $\mathrm{OC}(P$ $=0.104)$, being reflected in a general time effect $(P=$ 0.036; Figure 2). The amount of AT GLUT4 protein on $\mathrm{d}-21$ was lowest in group OC $(1.7 \pm 0.14 \mathrm{ng} / \mathrm{mL})$, different from group $\mathrm{O}(1.8 \pm 0.14 \mathrm{ng} / \mathrm{mL})$, which had the highest degree of protein expression $(P=0.002)$, and from group $\mathrm{T}(1.5 \pm 0.14 \mathrm{ng} / \mathrm{mL})$, which had an intermediate protein level $(P=0.024)$. From $\mathrm{d}-21$ to 21 GLUT4 protein amount in the AT of cows from

\section{$\square$ Thin $\square$ Optimal $\quad$ Over-conditioned}
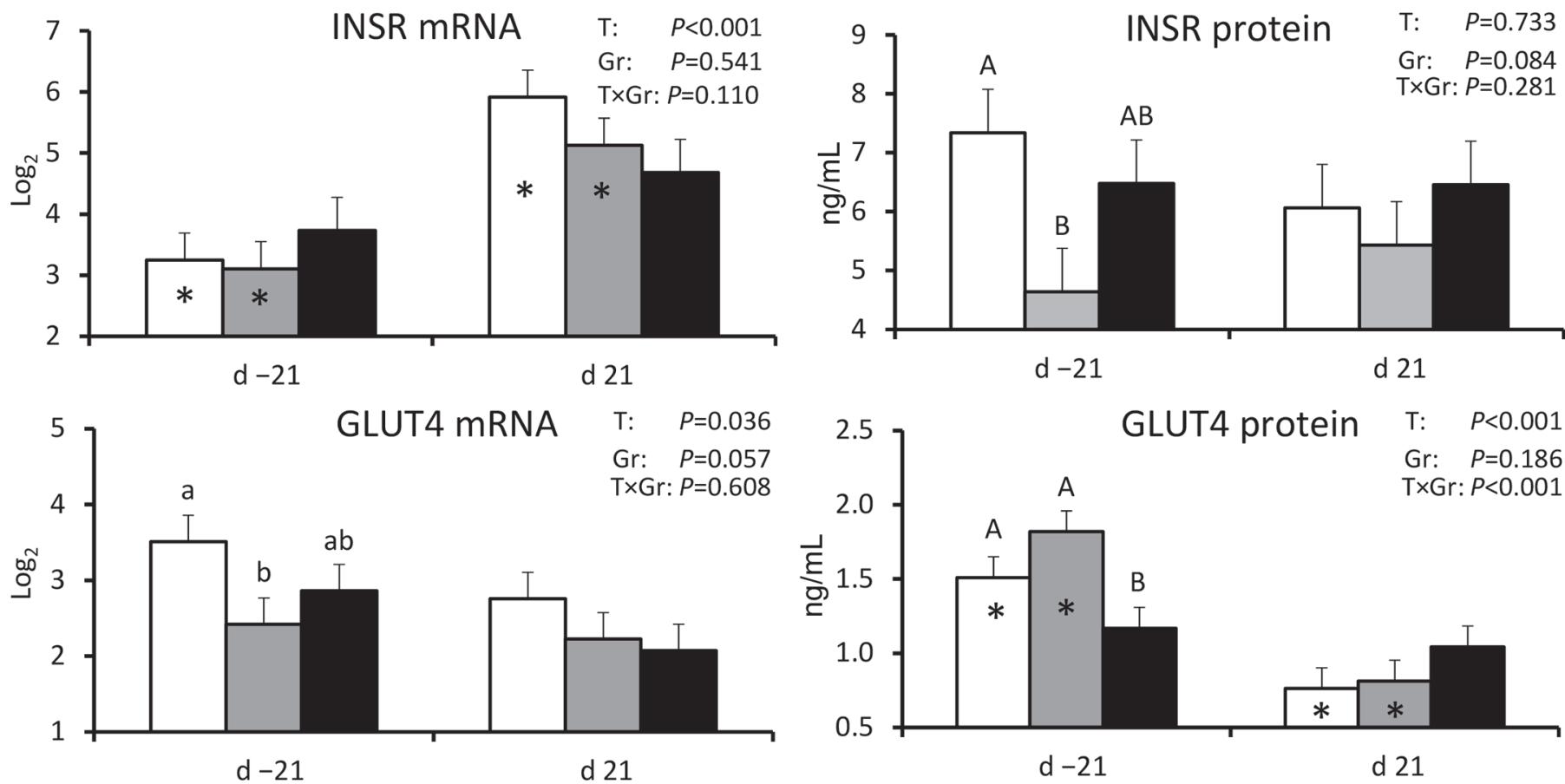

Figure 2. Adipose tissue mRNA and protein expression of insulin receptor (INSR, upper panels) and glucose transporter 4 (GLUT4, lower panels) $21 \mathrm{~d}$ before $(\mathrm{d}-21)$ and $21 \mathrm{~d}$ after calving (d 21) in multiparous Holstein dairy cows $(\mathrm{n}=42,14$ in each group) grouped according to BCS 4 wh before calving as follows: BCS $\leq 3.0$ (thin); BCS $=3.25-3.5$ (optimal); and BCS $\geq 3.75$ (overconditioned). Abundance of mRNA is expressed as delta cycle threshold $(\Delta \mathrm{CT})$ values $(2 \Delta \mathrm{CT})$; amount of proteins is presented as nanograms per milliliter, measured in homogenate after homogenization and centrifugation of samples. Mean values with different capital letters $(\mathrm{A}, \mathrm{B})$ indicate significant differences $(P \leq 0.05)$, and means with lowercase letters $(\mathrm{a}, \mathrm{b})$ represent a tendency to differ $(P \leq 0.1)$. Asterisks $(*)$ indicate significant changes over the time within the group. $P$-values given on the upper-right corner of the graphs refer to time $(\mathrm{T})$ and group $(\mathrm{Gr})$ effects and their interaction $(\mathrm{T} \times \mathrm{Gr})$. Error bars represent SEM. 
group OC did not change, but there was a clear decrease in protein levels in groups $\mathrm{T}$ and $\mathrm{O}(P<0.001)$, representing a general time effect $(P<0.001$; Figure 2$)$; significant differences between the groups disappeared on d 21 (Figure 2).

\section{DISCUSSION}

\section{Glucose Tolerance Test}

In our study we examined the effect of dry period body condition on the development and extent of IR during the transition period. However, the limitation of the study is missing intake data; therefore, we are unable to ascertain that observed changes and differences due to body condition have not been confounded by potential variation of cows DMI. General dynamics of blood glucose and insulin concentrations during the GTT in this study were similar in all experimental groups on both $\mathrm{d}-21$ and 21 . However, in all groups the magnitude of responses on d 21 was reduced compared with $d-21$. The increased clearance for glucose and reduced response for insulin in early lactation compared with late pregnancy is understood to be linked with the physiological homeorhetic adaptation to lactation (Debras et al., 1989; Mann et al., 2016a) and can be explained by greater insulin-independent glucose uptake by the udder and reduced insulin secretion during lactation (Bossaert et al., 2008). In addition, the elevated fatty acid concentrations in all groups of the present study on d 21 compared with d -21 could also have suppressed insulin secretion, as fatty acids may adversely influence pancreatic $\beta$-cell functions (Lewis et al., 2002; Stumvoll et al., 2005; Salin et al., 2012). However, when interpreting GTT results, it should be taken into account that glucose and insulin dynamics during the GTT characterize whole-body-level physiological responses and, due to the different physiological status of dry and lactating cows, are not comparable one-toone (DeKoster et al., 2017).

It is commonly accepted that the acquisition of adequate lipid stores during the dry period plays an important role in successful lactation and balanced metabolic status of cows (Drackley, 1999; Roche et al., 2013a). It is recommended that cows calve at an approximate BCS of 3.25 to 3.5 (Roche et al., 2009) and that cows do not lose or gain BCS during the dry period (Garnsworthy, 2006). Suboptimal BCS and overcondition at calving indicates inappropriate feeding during late lactation and the dry period, and is associated with the development of IR (Hove, 1978; Holtenius et al., 2003; Hayirli, 2006). In this study we observed the lowest blood insulin concentration on $\mathrm{d}-21$ in group $\mathrm{T}$, whereas group OC cows showed the highest insulin concentrations. Concomitantly we observed the lowest responses, both for blood glucose and insulin, during the GTT in group $\mathrm{T}$, intermediate in group $\mathrm{O}$, and the highest responses in group OC. Similarly, Holtenius et al. (2003) reported higher blood insulin concentration and more pronounced insulin responses during the GTT prepartum in overconditioned cows compared with those with optimal body condition and thin cows. As concluded (Holtenius et al., 2003), this was probably due to higher gastrointestinal uptake of insulinotropic precursors such as propionate and glycogenic AA, and thus a higher hepatic rate of glucose synthesis. Highest basal blood insulin concentration and a higher insulin response found in the current study during the GTT in group OC could also be related to obesity-induced $\beta$-cell proliferation. An increase in $\beta$-cell mass and insulin secretion has been reported in obese mice and humans (Linnemann et al., 2014). According to previous studies, malnutrition with the concurrently suboptimal BCS is supposed to be associated with decreased pancreatic insulin secretion ability (Hove, 1978; Hayirli, 2006; Oikawa and Oetzel, 2006). In the present study, from drying off until switched to the experiment, all cows maintained their BCS, which was the criterion for assignment of experimental groups. Thus, group $\mathrm{T}$ cows were thin already at drying off, which may have led to diminished pancreatic insulin secretion ability, being reflected in the lowest insulin response on $\mathrm{d}-21$ in group T. Due to the highest insulin response in group OC, the quickest glucose removal might also have been expected in this group. However, in the present study we observed the highest increment and largest AUC in OC cows, indicating slower removal of circulating glucose and consequently a higher degree of IR compared with the other groups. As proposed by Zachut et al. (2013), a greater insulin response to clear the same dose of glucose indicates the degree of IR. In addition, according to DeKoster et al. (2016b) of the characteristics derived from the i.v. GTT, AUC demonstrates good correlation with the results of hyperinsulinemic euglycemic clamp as a gold standard for assessment of degree of IR, in agreement with our finding of a more pronounced IR in OC cows. Contrary to our findings, probably due to differences in experimental design and conditions, different management and feeding during previous lactation, and different genetic background of cows, no effects of dry period feeding intensity or amount of body fat reserves on glucose and insulin responses before parturition were previously found in several studies (Schoenberg and Overton, 2011; Schoenberg et al., 2012; Mann et al., 2016a).

On d 21 the highest glucose increment in group OC differed from the lowest increment in group T. No other significant differences were present between the groups 
on d 21 in blood glucose or insulin responses during the GTT. Similar results have been obtained previously (Mann et al., 2016a). This could be explained by greater insulin-independent glucose consumption for milk synthesis, which can comprise up to $85 \%$ of all glucose available in the bloodstream (Knight et al., 1994; Zhao et al., 1996; Etherton and Bauman, 1998). Assuming constant milk synthesis throughout the day, glucose removal by the udder during the GTT exceeded the amount that was infused intravenously. Therefore, we speculate that observed responses for glucose and insulin in the current study in the main reflect the balance between constant insulin-independent removal of glucose and its short-term intravenous infusion. The proportion of insulin-dependent glucose consumption by peripheral tissues is likely small, and differences between the groups, if existent, might be overshadowed by the insulin-independent glucose removal and were not detected. However, Holtenius et al. (2003) reported reduced postpartum glucose disappearance during the GTT in overconditioned cows and attributed this to a more pronounced IR in obese cows. The highest glucose increment in OC cows, observed in the present study, could support this statement.

\section{Expression of INSR and GLUT4}

To assess insulin signaling efficiency and potential glucose consumption capability in AT, we measured abundance of mRNA and amount of proteins for INSR and GLUT4. As shown in earlier studies, the development of AT IR is associated with a decrease in the number and binding affinity of INSR on the surface of adipocytes in ewes (Guesnet et al., 1991), humans (Pessin and Saltiel, 2000), and nonruminant species (Flores-Riveros et al., 1993; Brennan et al., 2004; Suagee et al., 2011). Interestingly, in the current study, the abundance of AT INSR mRNA was higher on d 21 compared with d -21 independent of BCS, which might indicate increased postpartum insulin signaling capacity in AT compared with prepartum. These results are in agreement with Gross et al. (2011), reporting higher hepatic INSR mRNA abundance on wk 1 postpartum compared with wk 3 prepartum and during mid lactation, in cows with feed restriction-induced NEB compared with adequately fed controls. These findings were presumably due to low plasma insulin concentrations, which may have caused an upregulation of INSR expression to maintain hepatic insulin function, while maximizing nutrient supply to the mammary gland (Gross et al., 2011). However, in the current study mRNA potential did not lead to increased INSR protein expression on d 21 compared with $\mathrm{d}-21$. Furthermore, despite increased INSR mRNA abundance, along with largely unchanged INSR protein expression, we observed a decrease in GLUT4 mRNA abundance and protein expression on d 21 compared with d -21 . As there were no significant differences in AT INSR protein amounts pre- and postpartum, these results support the idea that, in ruminants, insulin signaling in adipocytes is related to signal transmission at the postreceptor, rather than to binding potential of insulin at the receptor level (Vernon and Taylor, 1988; Debras et al., 1989; Sasaki, 2002). It is also possible, that a decrease in GLUT4 expression could be a physiological response to low circulating glucose and insulin concentrations postpartum. Sadri et al. (2010) and Ji et al. (2012) observed downregulation of AT GLUT4 mRNA expression postpartum compared with prepartum, which is consistent with the present work. However, authors found no differences between the expression of INSR mRNA pre- and postpartum (Sadri et al., 2010; Ji et al., 2012). Sadri et al. (2010) concluded that INSR is not strongly involved in the reduction of insulin sensitivity in subcutaneous AT around parturition, whereas the change in insulin-dependent glucose uptake around parturition is regulated in part by GLUT4 presumably being downregulated by elevated fatty acid concentrations, observed also in current study. Ji et al. (2012) suggest that the lack of change in INSR mRNA expression around calving, indicating a defect in posttranslational modification of INSR, is likely to be a major mechanism exacerbating IR, whereas the decrease in expression of GLUT4 provided evidence for the reduced responsiveness of AT to insulin during early lactation. Similarly, Wiedemann et al. (2013) suggested that decreased GLUT4 expression contributes to the IR during early lactation more than downregulation of INSR. Mann et al. (2016b) assessed INSR protein concentrations in AT on d 28 prepartum and on d 21 postpartum. In contrast to our results, Mann et al. (2016b) reported a decrease in INSR protein concentration 21 d postpartum compared with 28 d prepartum, being part of the adaptation to lactation and outcome of the reduced concentrations of circulating glucose and insulin.

Regarding AT INSR and GLUT4 expression on d -21 , no differences were observed between the INSR mRNA abundances of the BCS groups, suggesting an equal capacity for insulin binding and expression of GLUT4 regardless of the amount of body fat stores. Unexpectedly, AT INSR protein concentration, as well as GLUT4 mRNA abundance on d -21 , differed between the group $\mathrm{T}$ with the highest and group $\mathrm{O}$ with the lowest INSR protein expression and GLUT4 mRNA abundance. According to Gross et al. (2011) malnutrition-related long-term hypoinsulinemia in thin cows caused an upregulation of the INSR expression. As 
mentioned earlier, in the present study, group $\mathrm{T}$ cows were thin already at drying off, which may have caused an upregulation of the INSR expression and consequently promoted transcription of GLUT4. In contrast, due to negative feedback, long-term hyperinsulinemia may cause decrease in the quantity of insulin receptors (Suagee et al., 2011) and GLUT4 in AT (Flores-Riveros et al., 1993; Brennan et al., 2004; Suagee et al., 2011). Furthermore, as concluded by Janovick and Drackley (2010) and Janovick et al. (2011), feeding a dairy cow in excess of requirements during gestation, even in the absence of overconditioning, may lead to hyperinsulinemic status. In the present study, blood insulin prepartum basal concentration in groups $\mathrm{OC}$ and $\mathrm{O}$ exceeded that in group $\mathrm{T}$, which might provide an explanation for reduced INSR protein and GLUT4 mRNA expression in these cows. The significantly lower GLUT4 protein concentration in group $\mathrm{OC}$ compared with groups $\mathrm{T}$ and $\mathrm{O}$ on $\mathrm{d}-21$, together with the GTT results, is a reflection of the reduced AT capability for glucose uptake in OC cows and provides evidence that in obese cows more pronounced AT IR already develops prepartum, regardless of insulin signaling potential. Similar to these results, no differences were reported shortly prepartum between INSR mRNA expression in cows fed the above requirements compared with those fed adequately (Ji et al., 2012). At the same time, Mann et al. (2016b) found a similar INSR protein expression in cows fed during the dry period either according to or above their requirements. In contrast to us, Ji et al. (2012) observed higher prepartum expression of GLUT4 in overfed cows, possibly due to different sampling time compared with the present study.

Similarly to the GTT results in the present study, no significant differences were observed among BCS groups for AT INSR or GLUT4 expressions on d 21. These results are in accordance with Ji et al. (2012) who reported no differences between INSR mRNA and GLUT4 mRNA expression on $\mathrm{d} 7$ and 21 postpartum in cows fed the above requirements before parturition. Those authors concluded that close-up energy overfeeding did not predispose animals to a more pronounced IR status. Similarly, Mann et al. (2016b) found no differences in INSR protein expression on d 21 between the controlled-energy-fed and overfed cows, leading authors to conclude that overfeeding during the dry period, despite high fatty acid and BHB concentrations postpartum, does not alter the response to a glucose-induced endogenous insulin stimulus in s.c. AT compared with cows fed a controlled diet. However, Zhang et al. (2013) reported that INSR mRNA abundance on d 21 postpartum was substantially lower in cows fed a high-energy diet during $21 \mathrm{~d}$ prepartum than in cows fed normal or low-energy diets, indicating that the response to insulin in overfed cows was significantly decreased. The present work implies that the amount of body fat reserves during the dry period does not affect AT insulin signaling potential and insulin-dependent glucose consumption capacity at the beginning of lactation. However, this conclusion does not exclude the possibility that the amount of dry period fat stores could influence AT IR in terms of lipolysis and lipogenesis. Indeed, OC cows had the highest plasma fatty acid concentration on $\mathrm{d} 21$ and greatest body condition loss from d -21 to 21 , indicating more intensive lipolysis. In addition, compared with groups $\mathrm{T}$ and $\mathrm{O}$, cows in the $\mathrm{OC}$ group partitioned more fat into milk and had the most negative energy balance, suggesting that overcondition during the dry period is related to intensified lipomobilization at the beginning of lactation. As AT INSR protein amounts on d 21 did not differ between the groups, the presumed inhibition of insulin signaling, along with more pronounced lipolysis in OC cows, probably occurs at the postreceptor signal transduction level.

\section{CONCLUSIONS}

The main hypothesis of our study was that the development and extent of IR during the transition period, mediated by the expression and function of INSR and GLUT4, is related to the amount of body fat reserves during the dry period. We demonstrated a considerably lower prepartum AT GLUT4 protein expression in overconditioned cows compared with optimal and thin cows, suggesting a reduced capacity for glucose uptake in the AT of overconditioned cows. This finding, together with the results of the GGT, provides evidence that in obese cows a more pronounced AT IR develops prepartum regardless of similar insulin signaling potential as in the thin and optimal cows, and is related to disturbed GLUT4 protein synthesis. As no significant differences were present between the groups' postpartum INSR and GLUT4 expression, the amount of body fat reserves during the dry period did not affect AT insulin signaling potential or insulin-dependent glucose uptake at the beginning of lactation. Therefore, these results suggest that, regarding glucose metabolism, body condition did not affect AT IR postpartum, but overconditioning during the dry period was related to intensified lipomobilization at the beginning of lactation.

\section{ACKNOWLEDGMENTS}

The study was supported by the Estonian Ministry of Education and Research (institutional research grant IUT 8-1, Fertility and Health in Dairy Cattle). We also thank the administration and technicians of Märja ex- 
perimental farm for their kind cooperation and technical help. Our deepest gratitude goes to Katri Pentjärv from Large Animal Clinic of the Estonian University of Life Sciences, who helped with tissue sampling and the glucose tolerance tests. We value the help from the personnel of the Feed and Metabolism Research Laboratory and Milk Quality Research Laboratory of the Department of Animal Nutrition for analyzing feed, milk, and blood samples, the expert laboratory work of Yolande Zbinden, Veterinary Physiology, Vetsuisse Faculty, University of Bern, and David Arney, Department of Animal Nutrition, Estonian University of Life Sciences, for linguistic correction of the manuscript. Finally, we appreciate everyone who has made an intellectual or tangible contribution to our research.

\section{REFERENCES}

AOAC. 2005. Official Methods of Analysis of AOAC International. 18th ed. W. Horwitz and G. W. Latimer, ed. AOAC International, Gaithersburg, MD.

Bell, A. W. 1995. Regulation of organic nutrient metabolism during transition from late pregnancy to early lactation. J. Anim. Sci. 73:2804-2819.

Bell, A. W., and D. E. Bauman. 1997. Adaptations of glucose metabolism during pregnancy and lactation. J. Mammary Gland Biol. Neoplasia 2:265-278.

Bobe, G., J. W. Young, and D. C. Beitz. 2004. Invited review: Pathology, etiology, prevention, and treatment of fatty liver in dairy cows. J. Dairy Sci. 87:3105-3124. https://doi.org/10.3168/jds .S0022-0302(04)73446-3.

Bossaert, P., J. L. M. R. Leroy, S. De Vliegher, and G. Opsomer. 2008. Interrelations between glucose-induced insulin response, metabolic indicators, and time of first ovulation in high-yielding dairy cows. J. Dairy Sci. 91:3363-3371.

Brennan, C. L., M. Hoenig, and D. C. Ferguson. 2004. GLUT4 but not GLUT1 expression decreases early in the development of feline obesity. Domest. Anim. Endocrinol. 26:291-301.

Cardoso, F. C., W. Sears, S. J. LeBlanc, and J. K. Drackley. 2011. Technical note: Comparison of 3 methods for analyzing areas under the curve for glucose and nonesterified fatty acids concentrations following epinephrine challenge in dairy cows. J. Dairy Sci. 94:6111-6115.

De Koster, J., M. Hostens, K. Hermans, W. Van den Broeck, and G. Opsomer. 2016b. Validation of different measures of insulin sensitivity of glucose metabolism in dairy cows using the hyperinsulinemic euglycemic clamp test as the gold standard. Domest. Anim. Endocrinol. 57:117-126. https://doi.org/10.1016/j.domaniend 2016.06.004.

De Koster, J., M. Hostens, M. Van Eetvelde, K. Hermans, S. Moerman, H. Bogaert, E. Depreester, W. Van den Broeck, and G. Opsomer. 2015. Insulin response of the glucose and fatty acid metabolism in dry dairy cows across a range of body condition scores. J. Dairy Sci. 98:4580-4592. https://doi.org/10.3168/jds.2015-9341.

De Koster, J., W. Van den Broeck, L. Hulpio, E. Claeys, M. Van Eetvelde, K. Hermans, M. Hostens, V. Fievez, and G. Opsomer. 2016a. Influence of adipocyte size and adipose depot on the in vitro lipolytic activity and insulin sensitivity of adipose tissue in dairy cows at the end of the dry period. J. Dairy Sci. 99:23192328. https://doi.org/10.3168/jds.2015-10440.

De Koster, J., M. Van Eetvelde, K. Hermans, W. Van den Broeck, M. Hostens, and G. Opsomer. 2017. Short communication: Limitations of glucose tolerance tests in the assessment of peripheral tissue insulin sensitivity during pregnancy and lactation in dairy heifers. J. Dairy Sci. 100:2381-2387. https://doi.org/10.3168/jds $.2016-11792$
De Koster, J. D., and G. Opsomer. 2013. Insulin resistance in dairy cows. Vet. Clin. North Am. Food Anim. Pract. 29:299-322. https://doi.org/10.1016/j.cvfa.2013.04.002.

Debras, E., J. Grizard, J. Aina, S. Tesseraud, C. Champredon, and M. Arnal. 1989. Insulin sensitivity and responsiveness during lactation and dry period in goats. Am. J. Physiol. 256(2 Pt.1):E295-E302.

Drackley, J. K. 1999. Biology of dairy cows during the transition period: The final frontier? J. Dairy Sci. 82:2259-2273.

Edmonson, A. J., I. J. Lean, L. D. Weaver, T. Farver, and G. Webster. 1989. A body condition scoring chart for Holstein dairy cows. J. Dairy Sci. 72:68-78. https://doi.org/10.3168/jds.S0022 -0302(89)79081-0.

Emmans, G. C. 1994. Effective energy: A concept of energy utilization applied across species. Br. J. Nutr. 71:801-821. https://doi.org/10 $.1079 /$ BJN19940188.

Etherton, T. D., and D. E. Bauman. 1998. Biology of somatotropin in growth and lactation of domestic animals. Physiol. Rev. 78:745761 .

Flores-Riveros, J. R., J. C. McLenithan, O. Ezaki, and M. D. Lane. 1993. Insulin down-regulates expression of the insulin-responsive glucose transporter (GLUT4) gene: Effects on transcription and mRNA turnover. Proc. Natl. Acad. Sci. USA 90:512-516.

Garnsworthy, P. C. 2006. Body condition score in dairy cows: Targets for production and fertility. Pages 61-86 in Recent Advances in Animal Nutrition. P. C. Garnsworthy and J. Wiseman, ed. Nottingham University Press, Nottingham, UK.

Goff, J. P. 2006. Major advances in our understanding of nutritional influences on bovine health. J. Dairy Sci. 89:1292-1301.

Gross, J., H. A. van Dorland, F. J. Schwarz, and R. M. Bruckmaier. 2011. Endocrine changes and liver mRNA abundance of somatotropic axis and insulin system constituents during negative energy balance at different stages of lactation in dairy cows. J. Dairy Sci. 94:3484-3494.

Guesnet, P. M., M. J. Massoud, and Y. Demarne. 1991. Regulation of adipose tissue metabolism during pregnancy and lactation in the ewe: The role of insulin. J. Anim. Sci. 69:2057-2065.

Hayirli, A. 2006. The role of exogenous insulin in the complex of hepatic lipidosis and ketosis associated with insulin resistance phenomenon in postpartum dairy cattle. Vet. Res. Commun. 30:749-774.

Holtenius, K., S. Agenas, C. Delavaud, and Y. Chilliard. 2003. Effects of feeding intensity during the dry period. 2. Metabolic and hormonal responses. J. Dairy Sci. 86:883-891. https://doi.org/10 3168/jds.S0022-0302(03)73671-6.

Holtenius, P., and K. Holtenius. 2007. A model to estimate insulin sensitivity in dairy cows. Acta Vet. Scand. 49:29-31.

Hove, K. 1978. Insulin secretion in lactating cows: Responses to glucose infused intravenously in normal, ketonemic, and starved animals. J. Dairy Sci. 61:1407-1413. https://doi.org/10.3168/jds .S0022-0302(78)83742-4.

Jaakson, H., K. Ling, J. Samarütel, A. Ilves, T. Kaart, O. Kärt, and M. Ots. 2013. Blood glucose and insulin responses during the glucose tolerance test in relation to dairy cow body condition and milk yield. Vet. Med. Zoot. 62:28-35.

Janovick, N. A., Y. R. Boisclair, and J. K. Drackley. 2011. Prepartum dietary energy intake affects metabolism and health during the periparturient period in primiparous and multiparous Holstein cows. J. Dairy Sci. 94:1385-1400. https://doi.org/10.3168/jds.2010 -3303 .

Janovick, N. A., and J. K. Drackley. 2010. Prepartum dietary management of energy intake affects postpartum intake and lactation performance by primiparous and multiparous Holstein cows. J. Dairy Sci. 93:3086-3102.

Ji, P., J. S. Osorio, J. K. Drackley, and J. J. Loor. 2012. Overfeeding a moderate energy diet prepartum does not impair bovine subcutaneous adipose tissue insulin signal transduction and induces marked changes in peripartal gene network expression. J. Dairy Sci. 95:4333-4351.

Kaneko, J. J., J. W. Harvey, and M. L. Bruss, ed. 2008. Clinical Biochemistry of Domestic Animals. Academic Press, Cambridge, MA.

Kärt, O., V. Karis, and M. Ots. 2002. Mäletsejaliste proteiintoitumine ja metaboliseeruval proteiinil põhinev söötade hindamise süsteem. 
Tartu. Eesti Põllumajandusülikooli Loomakasvatusinstituut. (in Estonian).

Knight, C. H., J. France, and D. E. Beever. 1994. Nutrient metabolism and utilization in the mammary gland. Livest. Prod. Sci. 39:129-137.

Lewis, G. F., A. Carpentier, K. Adeli, and A. Giacca. 2002. Disordered fat storage and mobilization in the pathogenesis of insulin resistance and type 2 diabetes. Endocr. Rev. 23:201-229.

Linnemann, A. K., M. Baan, and D. B. Davis. 2014. Pancreatic $\beta$-cell proliferation in obesity. Adv. Nutr. 5:278-288. https://doi.org/10 3945/an.113.005488

Mann, S., F. A. Leal Yepes, M. Duplessis, J. J. Wakshlag, T. R. Overton, B. P. Cummings, and D. V. Nydam. 2016a. Dry period plane of energy: Effects on glucose tolerance in transition dairy cows. J. Dairy Sci. 99:701-717. https://doi.org/10.3168/jds.2015-9908.

Mann, S., D. V. Nydam, A. Abuelo, F. A. Leal Yepes, T. R. Overton and J. J. Wakshlag. 2016b. Insulin signalling, inflammation, and lipolysis in subcutaneous adipose tissue of transition dairy cows either overfed energy during the prepartum period or fed a controlled-energy diet. J. Dairy Sci. 99:6737-6752. https://doi.org/10 $.3168 /$ jds.2016-10969

Oetzel, G. R. 2007. Herd-level ketosis-Diagnosis and risk factors. Preconference Seminar 7C: Dairy Herd Problem Investigation Strategies; Transition Cow Troubleshooting-American Association of Bovine Practitioners. 40th Annu. Conf., Vancouver, Canada. Am. Assoc. Bovine Pract., Auburn, AL.

Oikawa, S., and G. R. Oetzel. 2006. Decreased insulin response in dairy cows following a four-day fast to induce hepatic lipidosis. J. Dairy Sci. 89:2999-3005.

Oll, Ü. 1995. Feeding Requirements for Livestock with Feed Tables. Vabariiklik söötmisalase uurimistöö koordineerimise komisjon. Tartu. (in Estonian).

Pessin, J. E., and A. R. Saltiel. 2000. Signaling pathways in insulin action: Molecular targets of insulin resistance. J. Clin. Invest. 106:165-169

Roche, J. R., N. C. Friggens, J. K. Kay, M. W. Fisher, K. J. Stafford, and D. P. Berry. 2009. Invited review: Body condition score and its association with dairy cow productivity, health, and welfare. J. Dairy Sci. 92:5769-5801.

Roche, J. R., J. K. Kay, N. C. Friggens, J. J. Loor, and D. P. Berry. 2013a. Assessing and managing body condition score for the prevention of metabolic disease in dairy cows. Vet. Clin. North Am. Food Anim. Pract. 29:323-336.

Roche, J. R., K. A. Macdonald, K. E. Schutz, L. R. Matthews, G. A. Verkerk, S. Meier, J. J. Loor, A. R. Rogers, J. McGowan, S. R. Morgan, S. Taukiri, and J. R. Webster. 2013b. Calving body condition score affects indicators of health in grazing dairy cows. J. Dairy Sci. 96:5811-5825.

Sadri, H., R. M. Bruckmaier, H. R. Rahmani, G. R. Ghorbani, I. Morel, and H. A. van Dorland. 2010. Gene expression of tumour necrosis factor and insulin signalling-related factors in subcutaneous adipose tissue during the dry period and in early lactation in dairy cows. J. Anim. Physiol. Anim. Nutr. (Berl.) 94:e194-e202. https://doi.org/10.1111/j.1439-0396.2010.01005.x.

Salin, S., J. Taponen, K. Elo, I. Simpura, A. Vanhatalo, R. Boston, and T. Kokkonen. 2012. Effects of abomasal infusion of tallow or camelina oil on responses to glucose and insulin in dairy cows during late pregnancy. J. Dairy Sci. 95:3812-3825. https://doi.org/10 $.3168 /$ jds.2011-5206.

Samarütel, J., K. Ling, A. Waldmann, H. Jaakson, T. Kaart, and A. Leesmäe. 2008a. Field trial on progesterone cycles, metabolic profiles, body condition score and their relation to fertility in Estonian Holstein dairy cows. Reprod. Domest. Anim. 43:457-463. https://doi.org/10.1111/j.1439-0531.2007.00935.x.
Samarütel, J., A. Waldmann, K. Ling, H. Jaakson, T. Kaart, A. Leesmäe, and O. Kärt. 2008b. Relationships between luteal activity, fertility, blood metabolites and body condition score in multiparous Estonian Holstein dairy cows under different management. J. Dairy Res. 75:485-490. https://doi.org/10.1017/ S0022029908003610.

Sasaki, S. 2002. Mechanism of insulin action on glucose metabolism in ruminants. Anim. Sci. J. 73:423-433.

Saunja, L. O., L. Baevre, L. Junkkarinen, J. Pedersen, and J. Setala. 1991. A Nordic proposal for an energy corrected milk (ECM) formula. In Performance Recording of Animals: State of the art. P. Gailon and Y. Chabert, ed. Proceedings of the 27th Biennial Session of the International Committee for Animal Recording (ICAR), 2-6 July, 1990, Paris. EAAP Publication. 50:156-157.

Schoenberg, K. M., R. M. Ehrhardt, and T. R. Overton. 2012. Effects of plane of nutrition and feed deprivation on insulin responses in dairy cattle during late gestation. J. Dairy Sci. 95:670-682. https://doi.org/10.3168/jds.2011-4529.

Schoenberg, K. M., and T. R. Overton. 2011. Effects of plane of nutrition and 2,4-thiazolidinedione on insulin responses and adipose tissue gene expression in dairy cattle during late gestation. J. Dairy Sci. 94:6021-6035. https://doi.org/10.3168/jds.2011-4533.

Stumvoll, M., B. J. Goldstein, and T. W. van Haeften. 2005. Type 2 diabetes: Principles of pathogenesis and therapy. Lancet 365:13331346.

Suagee, J. K., B. A. Corl, M. W. Hulver, L. J. McCutcheon, and R. J. Geor. 2011. Effects of hyperinsulinemia on glucose and lipid transporter expression in insulin-sensitive horses. Domest. Anim. Endocrinol. 40:173-181.

Thorup, V. M., D. Edwards, and N. C. Friggens. 2012. On-farm estimation of energy balance in dairy cows using only frequent body weight measurements and body condition score. J. Dairy Sci. 95:1784-1793. https://doi.org/10.3168/jds.2011-4631.

Tuori, M., K. Kaustell, J. Valaja, E. Aimonen, E. Saarisalo, and P. Huhtanen. 1996. Rehutaulukot ja ruokintasuositukset. University of Helsinki, Department of Animal Science; Plant Production Inspection Center, Department of Agricultural Chemistry; Agricultural Research Center, Institute of Livestock Production Research, Helsinki, Finland. (in Finnish).

Vernon, R. G., and E. Taylor. 1988. Insulin, dexamethasone and their interactions in the control of glucose metabolism in adipose tissue from lactating and nonlactating sheep. Biochem. J. 256:509-514.

Vicari, T., J. J. G. C. van den Borne, W. J. J. Gerrits, Y. Zbinden, and J. W. Blum. 2008. Postprandial blood hormone and metabolite concentrations influenced by feeding frequency and feeding level in veal calves. Domest. Anim. Endocrinol. 34:74-88.

Wiedemann, S., G. Sigl, Ch. Schmautz, M. Kaske, E. Viturro, and H. H. D. Meyer. 2013. Omission of dry period or milking once daily affects metabolic status and is reflected by mRNA levels of enzymes in liver and muscle of dairy cows. Livest. Sci. 154:193-203. https://doi.org/10.1016/j.livsci.2013.02.016.

Zachut, M., H. Honig, S. Striem, Y. Zick, S. Boura-Halfon, and U. Moallem. 2013. Periparturient dairy cows do not exhibit hepatic insulin resistance, yet adipose-specific insulin resistance occurs in cows prone to high weight loss. J. Dairy Sci. 96:5656-5669. https://doi.org/10.3168/jds.2012-6142.

Zhang, Z., J. Wang, R. Gao, W. Zhang, X. Li, G. Liu, X. Li, Z. Wang, and X. Xhu. 2013. High-energy diet at antepartum decreases insulin receptor gene expression in adipose tissue of postpartum dairy cows. Bull. Vet. Inst. Pulawy 57:203-207. https://doi.org/ 10.2478/bvip-2013-0037.

Zhao, F., W. T. Dixon, and J. J. Kennelly. 1996. Localization and gene expression of glucose transporters in bovine mammary gland. Comp. Biochem. Physiol. B Biochem. Mol. Biol. 115:127-134. 